\title{
1 方向地震入力を受ける多層 1 軸偏心建物の各構面最大応答変位の推定手法 A SIMPLIFIED NONLINEAR ANALYSIS PROCEDURE FOR MULTI-STORY ASYMMETRIC BUILDINGS
}

\author{
藤井賢志*, 中埜良昭**, 真田靖士*** \\ Kenji FUJII, Yoshiaki NAKANO and Yasushi SANADA
}

\begin{abstract}
A simplified nonlinear analysis procedure to predict earthquake responses of multi-story asymmetric buildings is presented and some examples are shown in this paper. In this procedure, their responses are predicted through a nonlinear static analysis of MDOF model and estimation of seismic demand of equivalent SDOF model, considering the change in the first mode shape at each nonlinear stage and the effect of the first and second mode contribution. The results show that the responses of multi-story asymmetric buildings can be satisfactorily predicted by the proposed procedure.
\end{abstract}

Keywords: asymmetric building, equivalent first modal mass ratio, equivalent SDOF model, equivalent linearization 偏心建物， 1 次等価質量比，等価 1 自由度系モデル，等価線形化手法

1 はじめに

近年に世界中で開発が進められている性能評価型耐震設計法 ${ }^{1), 2), 3)}$ において，想定した地震動に対する建物の非線形态答の推定は最も重 要な項目の1つである.このための簡便な方法として，FEMA273で はNSP（Nonlinear Static Procedure） ${ }^{2)}$ ， 日本の改正建築基準法では限 界耐力計算法 ${ }^{3}$ に代表されるように，主としてねじれを伴わない整形 建物を対象として, これが強震時に単一のモードで振動すると仮定し て多自由度系モデルを等価 1 自由度系モデルに縮約して時刻歴応答 解析を行わずにその非線形応答を推定する手法が示されている4),s).

一方で平面的に不整形な偏心建物については，強震時に高次モード の影響が顕著となり単一の代表的なモードで振動しているとは見な せなくなる可能性がある事, 多方向入力の影響が顕著となる可能性が ある事，などからこれまでは上記の等価 1 自由度系モデルによる簡便 な忘答推定手法は適用の対象外とされてきた。また，近年これを多層 偏心建物に適用しようとする試みがいくつかなされているものの6,7), 十分な検討が未だなされていないのが現状である.しかしながら，偏 心建物に対しても前述の等価 1 自由度系モデルを用いた手法により その非線形応答の推定が可能となれば, 偏心建物の耐震性能を整形な 建物と統一的に議論できるようになるため，実用性が高いと思われる. そこで著者らは，偏心建物を対象とした等価 1 自由度系モデルによ る簡便な非線形地震応答推定手法をテーマに, その最も基本かつ重要 である 1 方向地震入力を受ける単層 1 軸偏心建物および各階の回転 半径が等しく重心が同一鈆直線上にあり，各階の㴊性偏心距離・耐力
偏心距離および弾力半径が等しいという条件を満足する多層 1 軸偏 心建物（以下では単純に多層 1 軸偏心建物と記す）を対象として各構 面の最大応答変位に特に着目してその推定手法の提案およびその適 用限界を論じてきた ${ }^{8) \sim 13)}$. そして，主としてせん断変形が卓越する低 層建物を対象とし，多層 1 軸偏心建物が構面方向からの 1 方向地震入 力を受ける場合に限定してその非線形地震応答推定手法を提案した 12), 13). 文献 12)にて著者らが示した手法の特徽は，1)筬略化モデルと して等価単層 1 軸偏心系モデルを導入し, 多層 1 軸偏心系モデルを等 価単層 1 軸偏心系モデルに縮約してから再度等価 1 自由度系モデルに 縮約する，2)各構面の塑性化の進展に伴うモード形の変動による影響 を考慮して等価 1 自由度系モデルを作成する，3)各構面の変位の推定 において，2 種類の外力分布による静的渐增載荷解析を行いその結果 を包絡することにより推定を行う，の3 点である.

本論文では, 初めに文献 12)で示した非線形地震応答推定手法の理 論的背景について概説を行い，特に偏心建物を縮約した等価 1 自由度 系モデルと多層平面骨組を縮約した等価 1 自由度系モデルの関係に着 目して議論を行う。次いで，既往の手法》と文献 12)で示した手法と の応答推定精度の比較を行う。

\section{2 等価単層 1 軸偏心系モテルと等価 1 自由度系モデルへの縮約 2.1 解析建物の仮定}

本論文において扱う多層 1 軸偏心建物を図 1 に示す. 本論文で議論 する非線形地震応答推定手法は以下の条件を满足する多層 1 軸偏心
* 東京工業大学 21世紀 COE 研究貝 ·博士 (工学)

***東京大学生産技術研究所 助教授. 工博

*** 東京大学地震研究所 助手・博士 (工学)
Post-Doctoral Research Fellow, Tokyo Institute of Technology, Dr. Eng. Assoc. Prof., Institute of Industrial Science, University of Tokyo, Dr. Eng. Research Assoc., Earthquake Research Institute, University of Tokyo, Dr. Eng. 


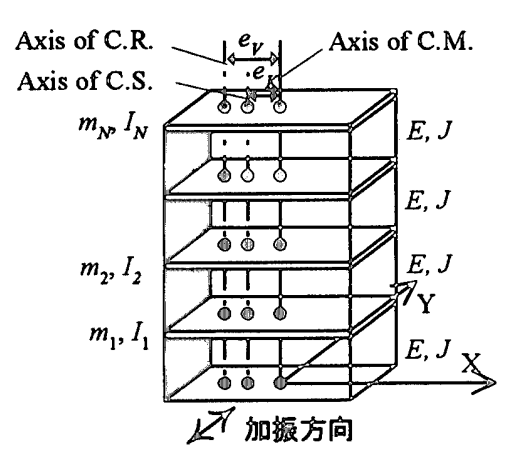

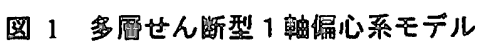

建物に適用するものとする.

1) 各階の平面形状が同一で回転半径 $r$ が等しいと見なす嘉ができる.

$$
r=\sqrt{I_{1} / m_{1}}=\sqrt{I_{2} / m_{2}}=\ldots \sqrt{I_{N} / m_{N}}
$$

ここで, $m_{i}$ : 各階啠量, $I_{i}$ : 各階回転慣性質量である.

2）各階の重心が同一鉛直線上にある.

3）建物を榙成する各榆面が互いに直交する方向に配置されている.

4) 各層の剛性偏心距離 $e_{K}$ ・耐力偏心距離 $e_{V}$ および重心に関する弹力 半径 $j$ が等しく, 互いに直交する方向の剛性および耐力の比が等 しい.

5）各層が概ね一様に塑性化するような耐力分布を有する.

6）式(2)で定義される 1 次等価質量比 $m_{1}{ }^{\circ}$ が十分に大きく, 建物の応答 において 1 次モード応答が支配的であると見なす余ができる。

$$
m_{1}{ }^{*}=M_{1} \cdot / \sum_{i=1}^{N} m_{i}=\beta_{1}^{2}\left(\left\{\phi_{1}\right\}^{T}[M]\left\{\phi_{1}\right\}\right) / \sum_{i=1}^{N} m_{i}
$$

ここで, $M_{1}^{\circ}$ は多層 1 軸偏心系モデルの 1 次等価質量, $\beta_{1}\left\{\phi_{1}\right\}$ は多層 1 軸偏心系モデルの 1 次モードの刺激関数, $[M]$ は多層 1 軸偏心系モ

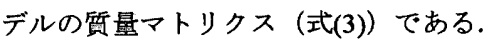

$[M]=\left[\begin{array}{ll}{[m]} & {[0]} \\ {[0]} & {[I]}\end{array}\right]$

$[m]=\left[\begin{array}{cccc}m_{1} & 0 & & 0 \\ 0 & m_{2} & \ddots & \\ & \ddots & \ddots & 0 \\ 0 & & 0 & m_{N}\end{array}\right],[I]=\left[\begin{array}{cccc}I_{1} & 0 & & 0 \\ 0 & I_{2} & \ddots & \\ & \ddots & \ddots & 0 \\ 0 & & 0 & I_{N}\end{array}\right]=r^{2} \cdot[m]$

本論文では，Y 軸に対してのみ偏心を有する多層せん断型 1 軸偏心 建物が $\mathrm{Y}$ 方向からの 1 方向地震入力を受ける場合を対象とする.

\section{2 等檤前屇 1 軸偏心系モテルの非線形運動方程式 9)}

図 1 に示した多層せん断型 1 軸偏心系モデルの弾性固有円振動数 $\omega_{k}$. 弾性固有モード $\left\{\phi_{k}\right\}$ はそれぞれ弾力半径比 $J(=j / r)$, 偏心比 $E$

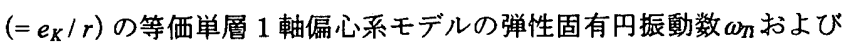
弾性固有モード $\left\{\phi_{\Pi}\right\} \quad\left(=\left\{\phi_{\Gamma \mathrm{N}}, \phi_{T Z Z}\right\}^{\mathrm{T}}\right)$ と，無偏心多層せん断系モデル の弾性固有円振動数 $\omega_{S j}$. 弾性固有モード $\left\{\phi_{S j}\right\}$ の直積の形となる事が志 賀により既に示されている ${ }^{14)}$ (式(5)〜(8)).

$$
\omega_{k}=\omega_{\pi i} \cdot \omega_{S J}
$$

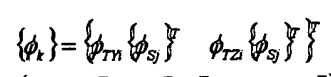

$\left(-\omega_{\pi}^{2}\left[\begin{array}{ll}1 & 0 \\ 0 & 1\end{array}\right]+\left[\begin{array}{cc}1 & -E \\ -E & J^{2}\end{array}\right]\right)\left\{\begin{array}{l}\phi_{T n} \\ \phi_{T Z}\end{array}\right\}=\left\{\begin{array}{l}0 \\ 0\end{array}\right\}$

$\left(-\omega_{s j}{ }^{2}[m]+\left[K_{Y}\right]\right)\left\{\phi_{s_{j}}\right\}=\{0\}$

ここで, 等価単層 1 軸偏心系モデルの回転成分 $Z$ について補足する. $z$ は回転角 $\theta$ に回転半径 $r$ を乗じて基準化したものであり, 固有モード の成分 $\phi_{\Upsilon Z i}$ と $\phi_{T \circledast i}$ の関係は式(9)で表される.

$$
\phi_{T \mathrm{Z}}=r \cdot \phi_{T \Theta}
$$

以下では無偏心多層せん断系モデルの弾性 1 次モード $\left\{\phi_{1}\right\}$ は最上 階成分が 1.0 となるように基準化し，等価単層偏心系モデルの弾性 1 次モード $\left\{\phi_{T_{1}}\right\}$ はY方向成分が 1.0 となるように基準化するものとする. 式(5)〜(8)の関係より多層 1 軸偏心系モデルの弾性 1 次モード刺激倸 数 $\beta_{1}$ および 1 次等価翼量比 $m_{1}{ }^{\circ}$ に関して式(10),(11)の関倸が得られる.

$\beta_{1}=\beta_{\pi} \cdot \beta_{S 1}$

$m_{1}^{*}=m_{T 1} \cdot m_{S 1}^{*}$

ここで, $\beta_{S 1}$ は無偏心多層せん断系モデルの弾性 1 次モード刺激保数, $\beta_{n}$ は等価単層 1 軸偏心系モデルの弾性 1 次モード刺激係数, $m_{S 1}{ }^{\circ}$ は無 偏心多層せん断系モデルの弾性 1 次等価翼量比, $m_{11}$ は等価単層偏心 系モデルの弾性 1 次等価質量比であり，それぞれ式(12)〜(14)で定義 される.

$\beta_{S 1}=\frac{\left\{\phi_{S 1}\right\}^{T}[m\}\{1\}}{\left\{\phi_{S 1}\right\}[m]\left\{\phi_{S 1}\right\}}, \beta_{T 1}=\frac{\phi_{T Y 1}}{\phi_{T Y 1}^{2}+\phi_{T Z 1}^{2}}=\frac{\phi_{T Y 1}}{\phi_{T Y 1}{ }^{2}+\left(r \cdot \phi_{T \Theta 1}\right)^{2}}$

$m_{S 1} \cdot=\frac{1}{\sum m} \cdot \beta_{S 1}\left\{\phi_{S 1}\right\}^{r}[m]\{1\}=\frac{1}{\sum m} \cdot \frac{\left(\left\{\phi_{S 1}\right\}^{T}[m]\{1\}\right)^{2}}{\left\{\phi_{S 1}\right\}^{T}[m]\left\{\phi_{S 1}\right\}}$

$m_{T 1}{ }^{\circ}=\beta_{T 1} \cdot \phi_{T Y 1}=\frac{\phi_{T Y 1}{ }^{2}}{\phi_{T Y 1}{ }^{2}+\left(r \cdot \phi_{T \ominus 1}\right)^{2}}$.

既往の検討において, 弾力半径比 $J$ が 1 より大きい場合には $m_{T}{ }^{\circ}$ が 大きくなる ${ }^{8)}$. 一方， 7 首以下で各階質量が等しく $\beta_{S 1}\left\{\phi_{S 1}\right\}$ 蒴逆三角形 となる場合には $m_{S 1}{ }^{\circ} か ゙ 0.8$ 以上であり, 層数による変動が小さい ${ }^{10)}$. 従って， $m_{1}$ が大きくなるケースは $J$ が大きい場合に対応する ${ }^{10), 13) . ~}$

一方, 1 方向地震入力を受ける多層 1 軸偏心系モデルの非線形運動 方程式は式(15)で表される.

$\left[\begin{array}{ll}{[m]} & {[0]} \\ {[0]} & {[I]}\end{array}\right]\left\{\begin{array}{l}\{\ddot{y}\} \\ \{\dot{\theta}\}\end{array}\right\}+\left[\begin{array}{ll}{\left[C_{Y Y}\right]} & {\left[C_{Y \theta}\right]} \\ {\left[C_{\theta Y}\right]} & {\left[C_{\theta \theta}\right]}\end{array}\right]\left\{\begin{array}{l}\{\dot{y}\} \\ \dot{\theta}\}\end{array}\right\}+\left\{\begin{array}{l}\left\{R_{Y}\right\} \\ \left\{M_{z}\right\}\end{array}\right\}=-\left[\begin{array}{cc}{[m]} & {[0]} \\ {[0]} & {[I]}\end{array}\right]\left\{\begin{array}{l}\{1\} \\ \{0\}\end{array}\right\} a_{8}(15)$ 式(15)における変数は以下に示す通りである.

$[C]=\left[\begin{array}{ll}{\left[C_{r r}\right]} & {\left[C_{r \theta}\right.} \\ {\left[C_{\theta r}\right]} & {\left[C_{\theta \theta}\right.}\end{array}\right]$ $\{R\}=\left\{\left\{R_{r}\right\}^{T} \quad\left\{M_{2}\right\}^{T}\right\}^{T}$ $\left.\{d\}=\{y\}^{T}\{\theta\}^{T}\right\}$ $a_{g}$
多層 1 軸偏心系モデルの減衰マトリクス : 多層 1 軸偏心系モデルの復元力ベクトル : 多層 1 軸偏心系モデルの変位ベクトル : 地動加速度 
ここで，無偏心多層せん断系モデルの 1 次モード形 $\beta_{S 1}\left\{\phi_{S 1}\right\}$ は線形・ 非線形を問わず一定であると仮定し，変位べクトル\{d\}を式(6)より式 (16)の形におく

$$
\left.\{d\}=\{y\}^{T} \quad\{\theta\}^{T}\right\}^{T}=\left\{\beta_{S I}\left\{\phi_{S I}\right\}^{T} \cdot Y_{1}^{*} \quad \beta_{S 1}\left\{\phi_{S I}\right\}^{T} \cdot \Theta_{1}^{\cdot}\right\}
$$

ここで， $Y_{1}^{*} ， \Theta_{1}^{*}$ はそれぞれ等価単層 1 軸偏心系モデルの等価重心変 位，等価回転角である．式(16)式を式(15)に代入する.

$\int[m]\left(\beta_{s 1}\left\{\phi_{s 1}\right\}\right) \cdot \ddot{Y}_{1}^{*}+\left[C_{r y}\right\}\left(\beta_{s 1}\left\{\phi_{s 1}\right\}\right) \cdot \ddot{Y}_{1}^{*}+\left[C_{Y \theta}\right)\left(\beta_{s 1}\left\{\phi_{S 1}\right\}\right) \cdot \dot{\Theta}_{1}^{*}+\left\{R_{Y}\right\}$ $=-[m\}\{1\} a_{8}$

$[I]\left(\beta_{s 1}\left\{\phi_{s 1}\right\}\right) \cdot \ddot{\Theta}_{1}+\left[C_{\theta z}\right]\left(\beta_{s 1}\left\{\phi_{s 1}\right\}\right) \cdot \dot{Y}_{1}^{*}+\left[C_{\theta \theta}\right\}\left(\beta_{s 1}\left\{\phi_{s 1}\right\}\right) \cdot \dot{\Theta}_{1}^{*}+\left\{M_{z}\right\}$ $l=\{0\}$

両辺の左側より $\beta_{S 1}\left\{\phi_{S 1}\right\}^{\mathrm{T}}$ を挂けて整理すると，等価単層 1 軸偏心系 モデルの非線形運動方程式（式(17)）を得る.

$\left[\begin{array}{cc}M_{T 1}^{*} & 0 \\ 0 & I_{\pi 1}\end{array}\right]\left\{\begin{array}{c}\ddot{Y}_{1}^{*} \\ \ddot{\Theta}_{1}^{*}\end{array}\right\}+\left[\begin{array}{cc}C_{Y T 1}^{*} & C_{Y \theta T}^{*} \\ C_{Y \theta T 1}^{*} & C_{\theta \theta T 1}^{*}\end{array}\right]\left\{\begin{array}{c}\dot{Y}_{1}^{*} \\ \dot{\Theta}_{1}^{*}\end{array}\right\}+\left\{\begin{array}{c}V_{y}^{*} \\ T_{z}^{*}\end{array}\right\}=-\left[\begin{array}{cc}M_{\pi}^{*} & 0 \\ 0 & I_{\pi 1}^{*}\end{array}\right]\left\{\begin{array}{l}1 \\ 0\end{array}\right\} a_{g}(17)$

式(17)における変数は以下の通りである.

$M_{T 1}^{*}=\beta_{S 1}\left\{\phi_{S 1}\right\}^{T}[m]\{1\}$

$I_{T 1}^{*}=\beta_{S 1}\left\{\phi_{S 1}\right\}^{T}[I]\{1\}=r^{2} \cdot M_{T 1} \cdot$

$\left[\begin{array}{cc}C_{Y Y T 1}^{*} & C_{\theta T 1}^{*}\end{array}\right]=\left[\beta_{S 1}{ }^{2}\left(\left\{\phi_{S I}\right\}^{T}\left[C_{r Y}\right\}\left\{\phi_{S 1}\right\}\right) \beta_{S 1}{ }^{2}\left(\left\{\phi_{S 1}\right\}\left[C_{Y \theta}\right\}\left\{\phi_{S 1}\right\}\right)\right.$

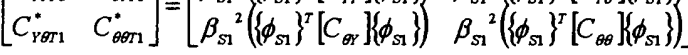

$\left\{\begin{array}{c}Y_{1}^{*} \\ \Theta_{1}^{*}\end{array}\right\}=\left\{\begin{array}{c}\beta_{S 1}\left\{\phi_{S 1}\right\}^{T}[m]\{y\} / M_{T 1}^{*} \\ \beta_{S 1}\left\{\phi_{S 1}\right\}^{T}[I]\{\theta\} / I_{T 1}^{*}\end{array}\right\},\left\{\begin{array}{c}V_{Y}^{*} \\ T_{z}^{*}\end{array}\right\}=\left\{\begin{array}{c}\beta_{S 1}\left\{\phi_{S 1}\right\}^{T}\left\{R_{Y}\right\} \\ \beta_{S 1}\left\{\phi_{S 1}\right\}^{T}\left\{M_{Z}\right\}\end{array}\right\}$

ここで, $M_{T 1}{ }^{*}, I_{T 1}{ }^{*}$ は等価単層 1 軸偏心系モデルの等価質量, 等価回 転慣性質量である. 等価単層 1 軸偏心系モデルの各構面要素の等価復

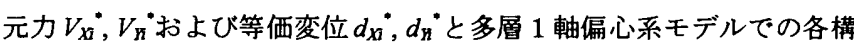
面の復元力ベクトル $\left\{R_{x i}\right\},\left\{R_{n}\right\}$ および変位ベクトル $\left\{d_{x i}\right\},\left\{d_{n}\right\}$ の関倸 はそれぞれ式(22)，(23)により表される。

$V_{x i}{ }^{*}=\beta_{S 1}\left\{\phi_{S 1}\right\}^{T} \cdot\left\{R_{x i}\right\}, V_{Y i}^{*}=\beta_{S 1}\left\{\phi_{S 1}\right\} \cdot\left\{R_{x_{i}}\right\}$

$d_{x i}=\beta_{S 1}\left\{\phi_{S 1}\right\}[m]\left\{d_{x i}\right\} / M_{T 1}{ }^{*}, d_{n i} \cdot=\beta_{S 1}\left\{\phi_{S 1}\right\}[m]\left\{d_{n i}\right\} / M_{T 1}$

等価単層 1 軸偏心系モデルの各構面要素の等価復元力一等価変位 関係は，変位分布を $\beta_{S 1}\left\{\phi_{S 1}\right\}$ に仮定して各構面を独立に静的漸增載荷解 析を行い，その結果を式(22)，(23)により $\left\{R_{x i}\right\},\left\{R_{n}\right\},\left\{d_{x k}\right\},\left\{d_{n !}\right\}$ を $V_{x i}$, $V_{n}^{*}, d_{x^{*}}{ }^{*} d_{n}{ }^{*}$ に変換することによって得られる.

\section{3 等価 1 自由度系モデルの非線形運動方程式}

式(17)の等価単層 1 軸偏心系モデルの運動方程式において，等価単 層 1 軸偏心系モデルの态答は線形・非線形を問わず 1 次モード応答が 支配的であると仮定して等価単層 1 軸偏心系モデルの重心变位べクト ル $\left\{Y_{1}^{*}, \Theta_{1}{ }^{*}\right\}^{\mathrm{T}}$ と等価復元力ベクトル $\left\{V_{Y}^{*}, T_{Z_{1}}^{*}\right\}^{\mathrm{T}}$ を式(24)の形におく.

$\left\{\begin{array}{l}Y_{1}^{*} \\ \Theta_{1}^{*}\end{array}\right\}=\beta_{T 1}\left\{\begin{array}{l}\phi_{T Y 1} \\ \phi_{T \Theta 1}\end{array}\right\} \cdot D_{1}^{*},\left\{\begin{array}{l}V_{Y}^{*} \\ T_{z}^{*}\end{array}\right\}=\left[\begin{array}{cc}M_{T 1}^{*} & 0 \\ 0 & I_{T 1}^{*}\end{array}\right]\left(\beta_{T 1}\left\{\begin{array}{l}\phi_{T Y 1} \\ \phi_{T \ominus 1}\end{array}\right\} \cdot A_{1}^{*}\right)$
ここで， $D_{1}$ 'は等価 1 自由度系モデルの等価変位， $A_{1}$ ”は等価 1 自由

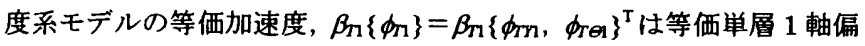
心系モデルの 1 次モード形である. 式(17)に式(24)を代入し，さらに 両辺の左側より $\beta_{n}\left\{\phi_{n}\right\}^{\mathrm{T}}$ を措けて整理すると，等価 1 自由度系モデル の非線形運動方程式（式(25)）を得る。

$\ddot{D}_{1}^{*}+\frac{C_{1}^{*}}{M_{1}^{*}} \cdot \dot{D}_{1}^{*}+A_{1}^{*}=-a_{8}$

ここで， $M_{1}$ “は等価 1 自由度系モデルの 1 次等価質量, $C_{1}$ “は等価 1 自由度系モデルの等価减衰係数であり，それぞれ式(26), (27)で定義 される.

$M_{1}^{*}=\beta_{T 1}{ }^{2}\left(\left\{\phi_{T 1}\right\}^{T}\left[\begin{array}{cc}M_{T 1}^{*} & 0 \\ 0 & I_{T 1} \cdot\end{array}\right]\left\{\phi_{T 1}\right\}\right)$
$C_{1}^{*}=\beta_{T 1}{ }^{2}\left(\left\{\phi_{T 1}\right\}^{T}\left[\begin{array}{ll}C_{Y T T 1} \cdot C_{y \theta r 1} \cdot \\ C_{\theta r T 1} & C_{\theta g T 1}\end{array}\right]\left\{\phi_{T 1}\right\}\right)$

以上の定式化は弾性 1 次モード形を用いて行ったが，等価単層 1 軸 偏心系モデルが非線形領域で㐫答する際にはモード形が著しく変動 する可能性がある. 本研究においては等価単層 1 軸偏心系モデルにお ける非線形領域での 1 次モード形は各要素の最大变形 (正負両領域で の大きい方の変形）に対する割線剛性により定まるものとし，式(24) 〜(27)での 1 次モード形 $\beta_{T}\left\{\phi_{T 1}\right\}$ は非線形領域では割線㴊性により定 まるモード形に読み替えるものとする.ここで，等価単層 1 軸偏心系 モデルの静的渐增載荷解析において各ステップの変位分布が非線形 領域での 1 次モード形と相似であるとすると，等価加速度 $A_{1}{ }^{*}$ と等価 変位 $D_{1}{ }^{*} お$ よび 1 次等価質量 $M_{1}{ }^{*}$ は式(28)〜(30)より求まる.

$A_{1}^{*}=\frac{1}{M_{1}^{*}} \beta_{T 1}\left\{\phi_{T 1}\right\}^{T}\left\{\begin{array}{l}V_{Y}^{*} \\ T_{z}^{*}\end{array}\right\}=\left\{1+\left(\frac{\Theta_{1}^{*}}{Y_{1}^{*}}\right) \cdot\left(\frac{T_{Z}^{*}}{V_{Y}^{*}}\right)\right\} \frac{V_{Y}^{*}}{M_{T 1}^{*}}$

$D_{1}^{*}=\frac{1}{\beta_{T 1}} \cdot Y_{1}^{*}=\left\{1+\frac{I_{T 1}^{*}}{M_{T 1}^{*}}\left(\frac{\Theta_{1}^{*}}{Y_{1}^{*}}\right)^{2}\right\} \cdot Y_{1}^{*}$

$M_{1}^{*}=\frac{1}{1+\left(I_{T 1}^{*} / M_{T 1}^{*}\right) \cdot\left(\Theta_{1}^{*} / Y_{1}^{*}\right)^{2}} \cdot M_{T 1}^{*}$

ここで，式(28)〜(30)は多層平面骨組に関して倉本らが示した式》) と等価なものであり，文献 11)に示す手法等を用いて非線形領域での モード形の変動を考慮した等価単層 1 軸偏心系モデルの静的渐增載 荷解析により等価 1 自由度系モデルの $A_{1}{ }^{*}-D_{1}{ }^{*}$ 関倸を得る事ができる 等価単層 1 軸偏心系モデルの 1 次モード形と等価 1 自由度系モデル の関倸を図 2 に示す. 図 2(a)に示すように等価質量 $M_{T}^{*}$ ，等価回転慣 性質量 $I_{n}{ }^{*}$ となる等価単層 1 軸偏心系モデルの 1 次モード応答は点 0 を回転の中心として回転振動しているものとすると、これに対応する 等価 1-自由度系モデルは図2(b)に示すように点Oにてピンで接合され た㴊体の先端 $\mathrm{A}$ に質量 $M_{1}$ が集中し，点 $\mathrm{O}$ に非線形回転バネがついた モデルとなる．ここで，重心から質量 $M_{1}$ “までの距離を $e_{1}$ とすると， 図 2 より式(31)の関係式が得られる. 


$$
\rho_{1} /\left(e_{1}+\rho_{1}\right)=\beta_{\tau_{1}} \phi_{T \gamma 1}
$$

ここで， $\rho_{1}$ は重心から回転中心までの距離であり，式(32)により定 義される.また，等価単層 1 軸偏心系モデルの刺激関数 $\beta_{n}\left\{\phi_{T n}\right\}$ は, 式(14)と式(32)より式(33)の形となる. 式(33)を式(31)に代入して整理 すると式(34)を得る。

$$
\begin{aligned}
& \rho_{1}=\left|\phi_{T Y 1} / \phi_{T \vartheta 1}\right| \\
& \beta_{T 1} \phi_{T Y 1}=\frac{\phi_{T Y 1}{ }^{2}}{\phi_{T Y 1}{ }^{2}+\left(r \cdot \phi_{T \ominus 1}\right)^{2}}=\frac{1}{1+\left(r \cdot \phi_{T \vartheta 1} / \phi_{T Y 1}\right)^{2}}=\frac{1}{1+\left(r / \rho_{1}\right)^{2}} \\
& e_{1}=r \cdot\left(r / \rho_{1}\right)
\end{aligned}
$$

式(34)は，回転中心 $\mathrm{O}$ から重心までの距離 $\rho$ と重心から質量 $M_{1}^{\circ} ま$ での距離を $e_{1}$ とは逆比例の関倸にあることを示している.すなわち， 1 次モードが純並進振動である場合 $\left(\rho_{1}=\infty\right)$ には重心から質量 $M_{1}{ }^{\circ}$ までの距離を $e_{1}$ は 0 となり質量 $M_{1}^{\circ}$ の位置は重心と一致する.また， 1 次モードが純ねじれ振動（ $\left.\rho_{1}=0\right)$ の場合には $e_{1}=\infty$ となる.

式(34)は以下のようにしても得る事ができる. 図2(a)において点 $O$ に関するモーメントMoa式(24)より式(35)で表される.また, 図2(b) において点Oに関するモーメントMobは式(36)で表される。

$$
M_{O a}=M_{T 1}^{0} \cdot \beta_{T 1} \phi_{T 1} \cdot A_{1}^{0} \cdot \rho_{1}+I_{T 1}^{0} \cdot \beta_{T 1} \phi_{T \ominus 1} \cdot A_{1}^{0}
$$$$
M_{o b}=M_{1}^{*} \cdot A_{1}^{0} \cdot\left(\rho_{1}+e_{1}\right)
$$

式(35)と式(36)を等しいとおき，さらに式(19)，(26)，(32)を用いて整 理すると式(34)を得る.ここで，式(36)は回転中心 $\mathrm{O}$ に関するモーメ ントは 1 次等価質量 $M_{1}{ }^{\circ}$ と等価加速度 $A_{1}{ }^{\circ}$ の皘, すなわちベースシアー の1次モード成分と回転中心 $\mathrm{O}$ から啠量 $M_{1}^{\circ}$ までの距離 $\left(\rho_{1}+e_{1}\right)$ の樌で ある事を示している. 一方で多層平面骨組の振動において, 転倒モー メントの1次モード成分はベースシアーの1次モード成分と 1 次モー ドに関する等価高さ $H_{1}{ }^{\circ}$ の積で表される ${ }^{15)}$. 従って, 回転中心 $O$ から 質量 $M_{1}^{*}$ までの距離 $\left(\rho_{1}+e_{1}\right)$ は多層平面骨組の振動における等価高さ $H_{1}$ と学的に等価である事がわかる.

\section{3 等価 1 自由度系による非線形地震応答推定手法の流れ 3.1 本研究で提案する非線形地震応答推定手法}

等価 1 自由度系による非線形地震㐫答推定手法の流れは以下に述 ベる. 詳細は文献 12)を参照されたい。

STEP 1 各構面の静的漸增載荷解析と等価単層 1 軸偏心系モデル の作成

STEP2 等価単層 1 軸偏心系モデルの静的漸增載荷解析と等価 1 自由度系モデルの作成

STEP 3 等価 1 自由度系モデルの非線形応答の推定

STEP 4 等価単層 1 軸偏心系モデルの応答の推定

STEP 5 各棒面の層間変位の推定

ここで, STEP 4 での等価単層 1 軸偏心系モデルの态答の推定におい ては文献 11)の知見に基づき, 1 次モードによる静的漸增載荷解析と籣 略化したモード直和外力による静的漸増載荷解析を併用して各構面 の等価変位を推定するものとする，なお，本論文では STEP 3 におけ る等価 1 自由度系モデルの非線形応答の推定は時刻歴応答解析を行
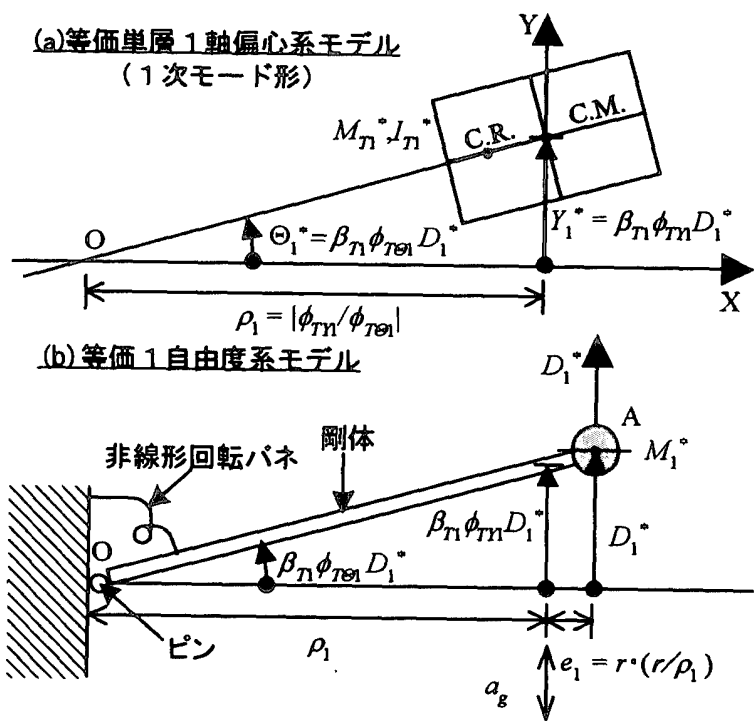

图 2 等価 1 自由度系モデル

わず, 文献 16)に示されている等価線形化手法により行うものとする. 本論文では, 等価 1 自由度系モデルの等価加速度 $A_{1}{ }^{\circ}$-等価变位 $D_{1}{ }^{\circ}$ 関保は，最上階での重心変位が建物高さの $1 / 100$ の点において履歴吸 収面樌が等しくなるように完全弾塑性型に置換するものとし，等価 1 自由度系の等価減衰定数 $h_{e q}$ は式(37)により定めるものとする.

$h_{e q}=0.25\left(1-1 / \sqrt{\mu_{\text {SDOF }}}\right)+h_{0}$

ここで， $\mu_{S D O F}$ 等価 1 自由度系モデルの塑性率であり， $A_{1}{ }^{\circ}-D_{1}{ }^{\circ}$ 関 係を完全弾塑性型に置換した時の折九点を降伏变位として求めた， $h_{0}$ は弾性時における隇衰定数である.ここでは， $h_{0}$ は $3 \%$ と設定した。 なお，式(37)は曲げ破壊する鉄筋コンクリート造（以下 RC 造と表記） 部材を想定して，ひび割れを無視した剛性低下型バイリニアーモデル

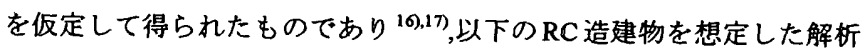
例で用いるのは妥当であると判断した。

\subsection{N2 method と本研究での提案する手法との比較}

P. Fajfar らは多自由度系モデルの非線形地震応答を等価 1 自由度系 モデルの非線形応答解析と多自由度系モデルの静的漸增載荷解析に

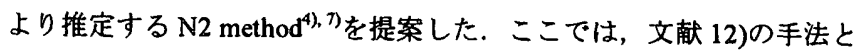
N2 method の相違点を以下に列举する.

第 1 の相違点は, 多自由度系モデルの静的漸增載荷解析の方法であ る.すなわち，N2 method では多層立体モデルを直接用いて，単一か つ一定の外力分布を用いて静的漸增載荷解析を行うため, 多層立体モ デルの静的濑増载荷解析を必要とし, また塑性化の進展に伴うモード 形の変動は考慮されない. N2 method では多層立体モデルの静的渐增 载荷解析で用いられる外力分布 $\{P\}$ を式(38)で仮定する.

$\{P\}=[M]\{\Phi\}=\left[\begin{array}{ll}{[M]} & {[0]} \\ {[0]} & [I]]\end{array}\right]\left\{\begin{array}{l}\left\{\Phi_{Y}\right\} \\ \left\{\Phi_{\Theta}\right\}\end{array}\right\}$

ここで\{Ф\}は仮定した変位分布である．ここで簡略化のため回転成 分 $\left\{\Phi_{\otimes}\right\}$ を無視して $\{0\}$ とおくと，\{P\}は式(39)により定まる. 


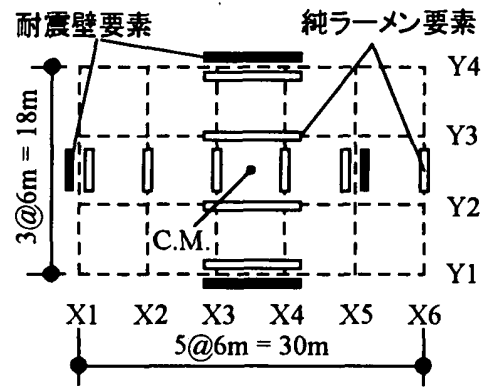

(a1) Model-A1

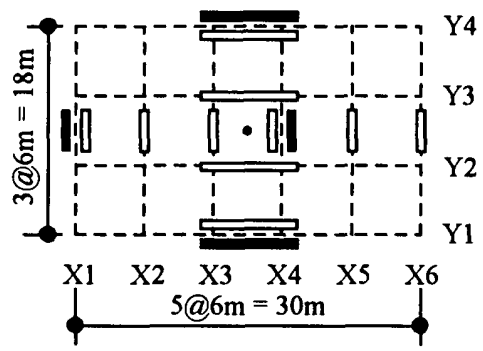

(b) Model-B

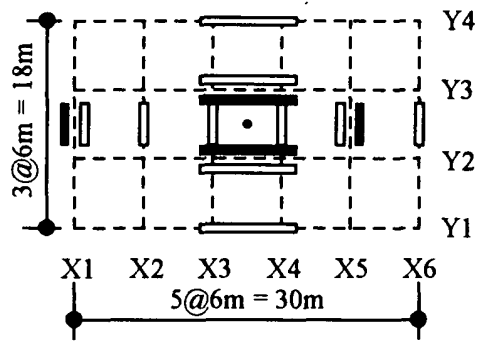

(a2) Model-A2

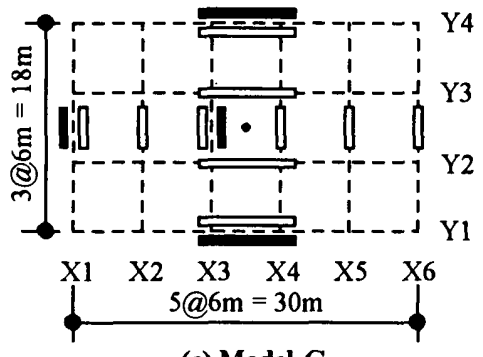

(c) Model-C

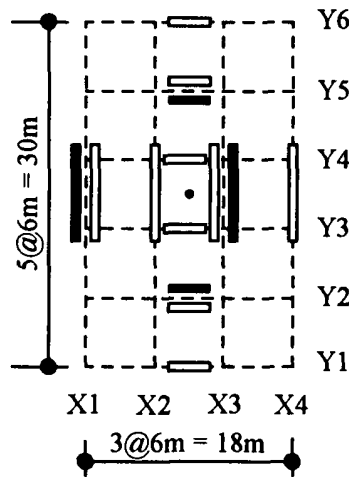

(a3) Model-A3

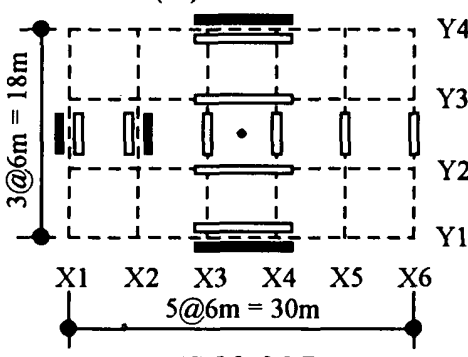

(d) Model-D

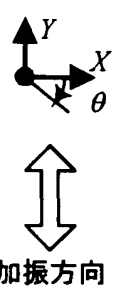

加振方向

图 3 解析建物モデルの平面图

$\{P\}=[M]\} \Phi\}=\left[\begin{array}{cc}{[M]} & {[0]} \\ {[0]} & [I]]\end{array}\right]\left\{\begin{array}{c}\left\{\Phi_{Y}\right\} \\ \{0\}\end{array}\right\}=\left\{\begin{array}{c}{[M]\left\{\Phi_{Y}\right\}} \\ \{0\}\end{array}\right\}$
式(39)は，外力としては重心に水平力のみを作用させる事を示して いる点に留意されたい. P. Fajfar ら》は式 (39) による外力分布を用い て静的漸增載荷解析を行っている.

第 2 の相違点は, N2 Method においては等価 1 自由度系モデルの作 成に際してモード形の変動を無視している点である.N2 Method では, 等価 1 自由度系モデルの等価変位 $D_{1}^{*}$, 等価加速度 $A_{1}$ 'は最上階重心変 位 $y_{N}$, ベースシアー $V_{n}$ と式(40)により関保づけられている。

$D_{1}^{*}=y_{N} / \Gamma, A_{1}^{*}=V_{Y_{1}} /\left(\Gamma m^{*}\right)$

ここで，式(40)におけるГは刺激係数に， $\Gamma \mathrm{m}^{*}$ は等価質量に相当し， 変位分布 $\{\Phi\}$ の回転成分 $\left\{\Phi_{\boldsymbol{\theta}}\right\}$ を無視した場合では式(41)より定まる.

$\Gamma=\frac{\left\{\Phi_{Y}\right\}^{T}[m]\{1\}}{\left\{\Phi_{Y}\right\}^{T}[m]\left\{\Phi_{Y}\right\}}, \Gamma m^{*}=\frac{\left(\left\{\Phi_{Y}\right\}^{T}[m]\{1\}\right\}^{2}}{\left\{\Phi_{Y}\right\}^{T}[m]\left\{\Phi_{Y}\right\}}$

式(39)，(41)より，N2 Method では変位分布 $\{\Phi\} の$ 仮定が応答推定精 度に最も影響を与えることが推察される。

\section{4 解析諸元}

\section{1 解析建物モテル}

解析対象は図 3 に示す 6 種類の平面形状のせん断型多層 1 軸偏心建 物モデルとした. 平面形状は各階で同一とし, 層数は低層建物を想定 して 4 層とした，建物の階高は全て等しく $3.60 \mathrm{~m}$ ，建物の各階の慣性 質量 $m$ と回転慣性質量 $I$ は全ての階で等しく $648 \mathrm{ton}, 6.61 \times 10^{4} \mathrm{ton} \cdot \mathrm{m}^{2}$ とした. 建物の降伏ベースシアー倸数は, 加振方向であるY方向, 加 振直交方向であるX方向ともに 0.6 とし, 各構面に図 4 に示寸復元力
特性を有する純ラーメン要素, 耐震壁要素が配㯰されているものと仮 定した．各層の降伏耐力 $V_{i}$ は式(42)で定めた.

$V_{i}=\frac{N+i}{N+1} \cdot 0.6 \cdot\left(\sum_{j=i}^{N} m\right) \cdot g$

ここで, $N$ は層数，iは対象層， $\mathrm{g}$ は重力加速度 $\left(=9.8 \mathrm{~m} / \mathrm{s}^{2}\right)$ である. 純ラーメン要素と耐震壁要素の降伏耐力は, $\mathrm{X}, \mathrm{Y}$ 方向ともに純ラー メン要素は合計で $1 / 3 V_{i}$ とし, 耐震壁要素では合計で $2 / 3 V_{i}$ とした. 各要素の復元力特性は曲げ破壊型の RC 部材の挙動を想定して Takeda モデル ${ }^{18)}$ を用いた。 なお, 全モデルにおいて全層で弾力半径比 $J$ と偏 心比 $E$ の值は同一となり，偏心を無視した場合の 1 次モード形は逆三 角形となる. 表 1 に各モデルのパラメータとして, 弾力半径比 $J$, 偏

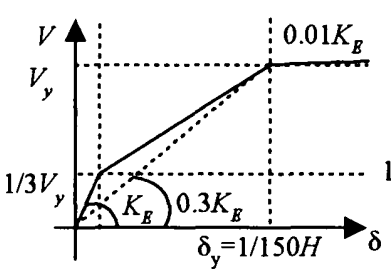

(a) 純ラ一メン要椂

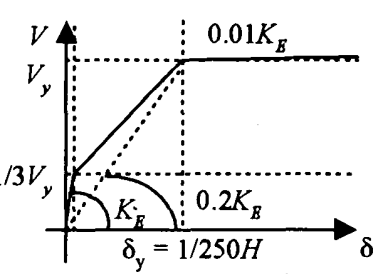

(b) 耐带壁要素
图 4 各要素の復元力特性

表 1 各モデルの各パラメータ

\begin{tabular}{lcccccc}
\hline & $J$ & $E$ & $R e^{19)}$ & $T_{1}(\mathrm{~s})$ & $T_{2}(\mathrm{~s})$ & $m_{1}{ }^{*}$ \\
\hline Model-A1 & 1.469 & 0.248 & 0.171 & 0.252 & 0.165 & 0.800 \\
Model-A2 & 1.252 & 0.248 & 0.202 & 0.258 & 0.190 & 0.731 \\
Model-A3 & 1.129 & 0.248 & 0.225 & 0.266 & 0.206 & 0.619 \\
Model-B & 1.365 & 0.495 & 0.389 & 0.279 & 0.170 & 0.690 \\
Model-C & 1.365 & 0.743 & 0.649 & 0.324 & 0.162 & 0.626 \\
Model-D & 1.469 & 0.913 & 0.990 & 0.374 & 0.153 & 0.627 \\
\hline
\end{tabular}


表 2 模擬地罢動の一覧

\begin{tabular}{|c|c|c|c|}
\hline 実記録 & 模擬地霞動 & $\begin{array}{c}\text { 模擬地震動の } \\
\text { 最大加速度 } \\
\left(\mathrm{m} / \mathrm{s}^{2}\right)\end{array}$ & $\begin{array}{c}\text { 模擬地解動の } \\
\text { 最大速度 } \\
(\mathrm{m} / \mathrm{s})\end{array}$ \\
\hline ELC & JCode-ELC & 5.703 & 0.790 \\
\hline TAF & JCode-TAF & 6.064 & 0.728 \\
\hline HAC & JCode-HAC & 5.210 & 0.647 \\
\hline $\mathrm{TOH}$ & JCode-TOH & 5.676 & 0.970 \\
\hline JKB & JCode-JKB & 6.507 & 0.890 \\
\hline FKI & JCode-FKI & 5.892 & 0.953 \\
\hline
\end{tabular}

心比 $E$, 基準法における偏心率 $R e^{19}$ と固有周期 $T_{1}, T_{2}, 1$ 次等価罂量比 $m_{1}{ }^{\circ}$ を示す，表 1 より明らかなように, 各モデルの 1 次等価質量比 $m_{1}{ }^{\circ}$ は0.619〜0.800の節囲となっており，2.1で述べた条件 6)を满足して 1 次モード応答の寄与分が大きいモデルとなっている.

4.2 入力地震動

入力地霞動はY 方向からの 1 方向入力とした. 入力地䈨動は告示で 規定された設計用応答スペクトル（減衰定数 $h=5 \%$ ）に適合するよう に作成した模擬地霞動とした ${ }^{19}$. 入カレベルは極めて稀に生じる地霞

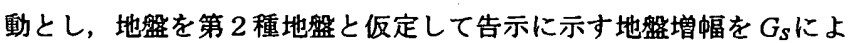
り考慮した，模擬地霞動の位相特性は El Centro 1940NS (ELC), Taft 1952NS (TAF), Hachinohe 1968EW (HAC), Tohoku Univ. 1978NS (TOH), JMA Kobe 1995NS (JKB), Fukiai 1995 N30E (FKI)の位相特性を用い, 継続時間は 40.96s とした. 作成した模擬地叞動の一筧を表 3 に，加速 度応答スペクトル（減衰定数 $h=5 \%$ ）を図 5 に示す.

4.3 解析ケース

\subsection{1多層 1 軸偏心系モデルによる非線形時刻歴虑答解析}

数值䅡分法は Newmark- $\beta$ 法 $(\beta=1 / 4)$ を用い，筧分時間刻みは 0.005 秒とした。減衰は瞬間唎性比例型とし，弾性 1 次モードに対して $3 \%$ と仮定した.

\subsection{2簡便な手法による非線形応答の推定}

等価 1 自由度系モデルによる非線形応答の推定は 3 種類の方法によ

り行う. Case 1 は，P. Fajfar らによるN2 methodである. Case 1 にお いて仮定する变位分布 $\{\Phi\} \quad\left(=\left\{\left\{\Phi_{\mathrm{Y}}\right\}^{\mathrm{T}},\left\{\Phi_{\circledast}\right\}^{\mathrm{T}}\right\}^{\mathrm{T}}\right)$ は， $\left\{\Phi_{\mathrm{Y}}\right\}$ は逆三角形

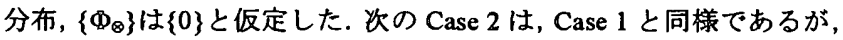
仮定する変位分布 $\{\Phi\}$ として弾性時の 1 次モード形を用いた。すなわ

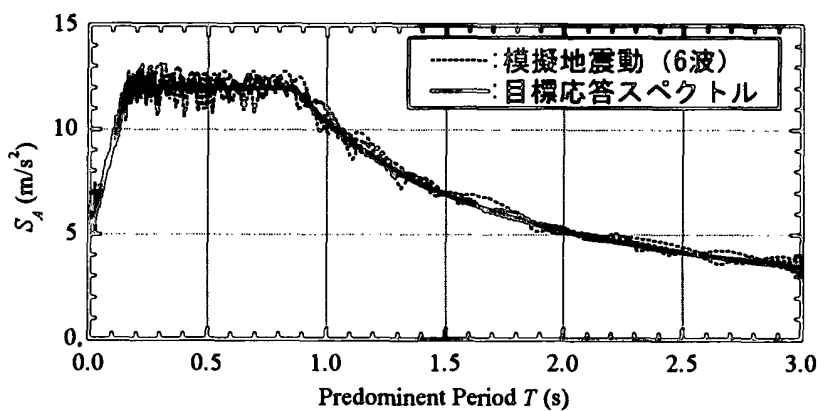

圆 5 證擬地震動の放速度底答スペクトル

ち Case 2 では, $\{\Phi\} の$ 回転成分 $\left\{\Phi_{\circledast}\right\}$ は $\{0\}$ とはならないため, 静的渐 增載荷解析における外力分布 $\{\mathrm{P}\}$ は式(39)より定める．また，式(40)に おけるГおよび, $\Gamma m^{\circ}$ は式(41)の代わりに式(43)より定めた.

$\Gamma=\frac{\left\{\Phi_{Y}\right\}^{T}[m]\{1\}}{\left\{\Phi_{Y}\right\}^{T}[m]\left\{\Phi_{Y}\right\}+\left\{\Phi_{\Theta}\right\}^{T}[I]\left\{\Phi_{\Theta}\right\}}, \Gamma m^{\circ}=\frac{\left(\left\{\Phi_{Y}\right\}^{T}[m]\{1\}\right\}^{T}}{\left\{\Phi_{Y}\right\}^{T}[m]\left\{\Phi_{Y}\right\}+\left\{\Phi_{\Theta}\right\}^{T}[I\}\left\{\Phi_{\odot}\right\}}(43)$

最後のCase 3 は, 本研究により提案する非線形応答推定手法である なお，いずれのCaseにおいても等価 1 自由度系モデルの非線形応答

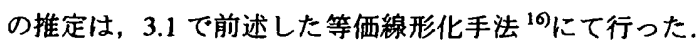

\section{5 经定精庭の比譬}

図 6 に多層 1 軸偏心系モデルによる時刻䇛応答解析結果（平均 $\mu$, 標準偏差 $\sigma$ ）と各ケースにおける最上階での各購面の最大态答変位の 推定結果を示す．図6より以下の点が指摘できる.まず Case 1 では, いずれのモデルにおいても Y 方向の構面では概ね時刻歴応答解析結 果の平均を大きめに評価している一方で，X方向の構面では 0.307〜 1.08 倍と過小評価となっている. 次に Case 2 では, Model-A1 以外の モデルでY方向の㓮側櫵面（棬面 X1）の変位を過小評価しており時 刻歷応答解析結果の平均の $0.143 \sim 1.26$ 倍となる一方で, 柔側榜面

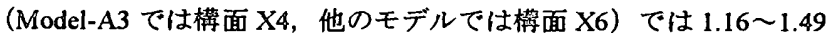
倍となっている．また，X方向の構面では Model-A3 では 5.48 倍と著 しく過大評価となっている一方で他のモデルでは1.23〜1.84倍となっ ている.Case 2 においてY方向剛側構面の変位を過小評価した要因は, 文献 11)で既に指摘したように例側構面では 2 次モード応答の影響が
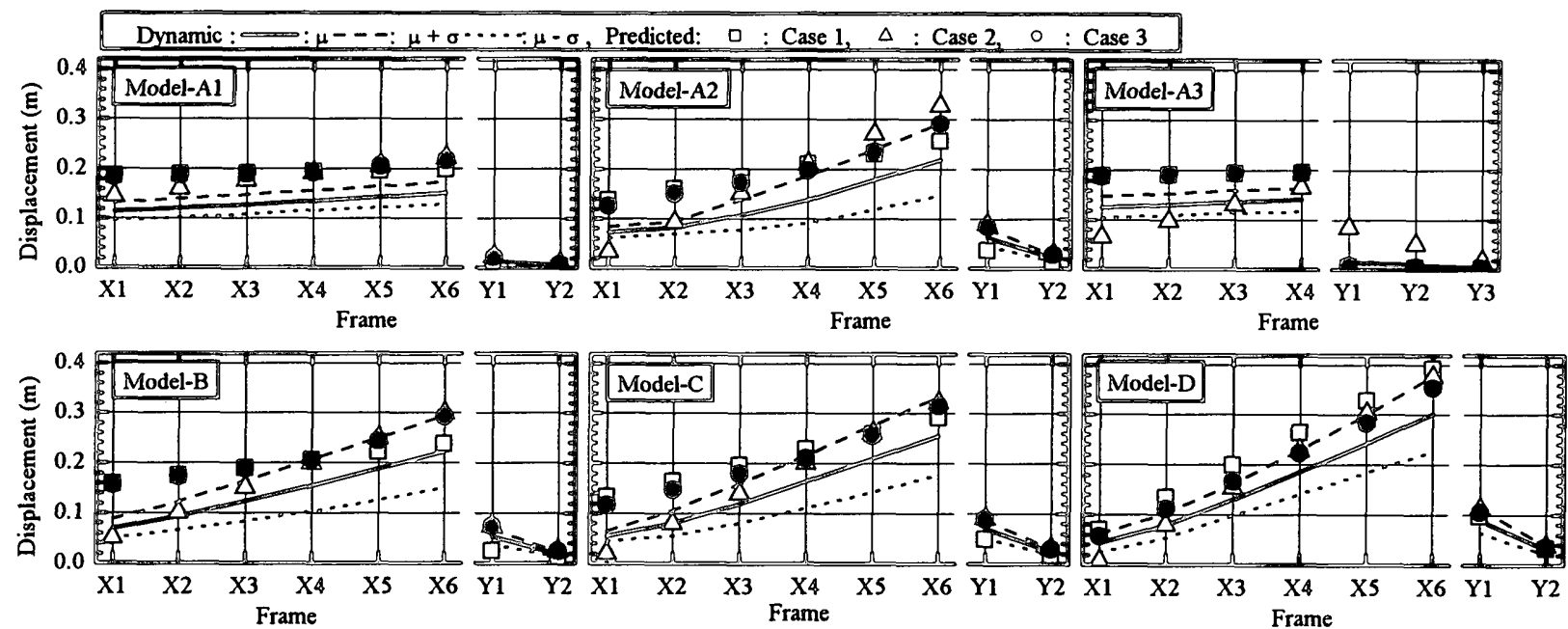

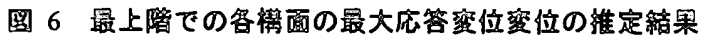


顕著となり，1 次モード応答のみによる評価では過小評価となるため である. 最後のCase 3 では，いずれのモデルにおいてもY方向の用 側構面では時刻歴応答解析結果の平均の $1.32 \sim 2.26$ 倍と過大評価する 傾向がある一方で, 柔側構面では1.17〜1.43 倍となっている.一方で, 加振直交方向である X 方向の構面では Model-A3 では 0.534 倍と過小 評価となっているものの, 他のモデルでは1.17〜1.67倍となっている. 以上により，3つの推定結果のうちで Case 3 が全ての構面において最 も安定した精度の推定結果となった.

なお, STEP 3 において，等価線形化手法により推定された等価 1 自 由度系モデルの応答は, 別途行った等価 1 自由度系モデルの時刻歴応 答解析結果を概ね大きめに評価する結果となった。従って，図 6 にお いて大きめに評価される結果となったのは文献 16)の等価線形化手法 による等価 1 自由度系の応答精度によるものであると思われる．

図 7 に全モデルでの剛側構面（構面 X1），柔側構面（Model-A3 では 構面 X4，それ以外のモデルでは構面 X6）および直交方向の構面 Y1 での最大層間変形角を示す。図 7 より明らかなように，時刻歴応答解 析結果では Model-A1，Model-A3 を除いては柔側構面（構面 X6）では 㴊側構面（構面 X1）の2 倍以上の変位が生じており，例えば ModelCでは最下層の柔側構面の最大層間変形角が平均で $2.0 \%$ (純ラーメ ン要素で塑性率 3.03）生じている一方, 最下層の㓮側構面の最大層間 変形角が平均で $0.57 \%$ （純ラーメン要素で塑性率 0.85）生じている. 一方で, 図6において最も対応の良好だったCase 3 による推定結果は 時刻歴解析結果と大局的には対応したものとなっているものの，層に よる精度のばらつきは大きく, 特に柔側構面の最上層, 最下層で顕著 である.なお, Model-C を用いて入力地震動の大きさを 0.7 倍にして
別途検討したところによると，構面 X6 の層間変形角は $1.13 〜 1.37 \%$ （純ラーメンの塑性率は1.70２.06）であり層によるばらつきは小さ く Case 3 によって全般的に精度良く推定することができた，従って， 文献 12)での応答推定手法による層間变形角の推定精度のばらつきは 非線形応答が增大するとともに增大寸る.

各ケースでの推定精度の違いを詳細に検討するため, 最上階での重 心変位・回転角に着目して議論を行う. 図 8 に最上階での重心変位 $y_{4}$ と回転角 $\theta_{4}$ について，等価 1 自由度系モデルによる推定結果と多層 1 軸偏心系モデルによる時刻歷応答解析結果（平均值）の比を示す. 図 8(a)において, 重心変位の推定精度は Case 1 では 1.42〜1.59 倍, Case 2 では 0.852〜1.46 倍, Case 3では 1.24〜1.49 倍となっており, 他と比 べて Case 2 では幅があり，特に Model-A3 では推定值が時刻歴応答解 析結果を下回っている.一方, 図 8(b)に示した回転角の推定精度は各 ケースで違いが著しく, Case 1では 0.307〜 1.08 倍となり最も偏心の 大きい Model-D を除いて全て過小評価となる一方で, Case 2 では Model-A3 で推定值は時刻歴応答解析結果の 5.48 倍と著しく過大評価 しているのを除けば 1.24〜1.84 倍となっている. 最後に Case 3 では Model-A3 では 0.534 倍と過小評価となっているものの, 他のモデルで は 1.17〜1.66 倍となっており，3者のうちで最も精度が良くなってい る.これは, Case 1 では静的漸增載荷解析において重心に水平力のみ しか作用させていないため，ねじれ応答を過小に見櫴もることになる 一方で, Case 2 ではモード形の変動が著しいモデルでは塑性化後の忘 答を評価し得ないためである. 図 9 に Model-A3 と Model-Bでの静的 漸増載荷解析結果による最上階重心变位と最上階回転角の関倸を時 刻歴応答解析結果と比較して示寸. 図 9 より明らかなように, Case 1

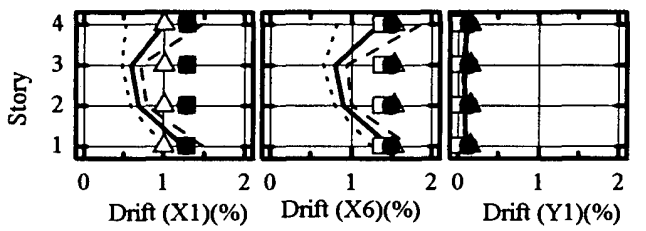

(a1) Model-A1

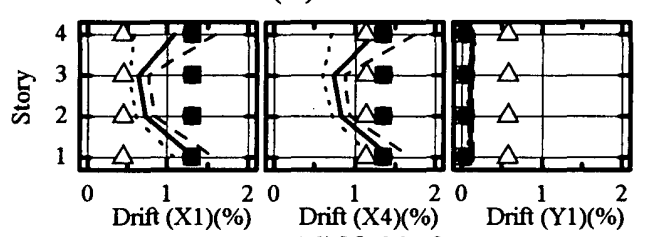

(a3) Model-A3

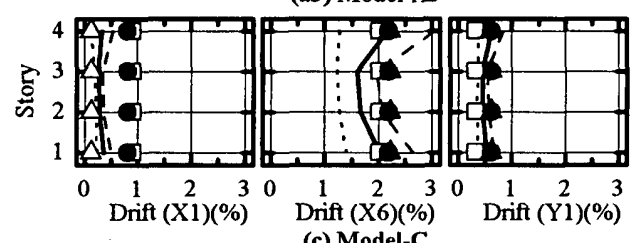

(c) Model-C

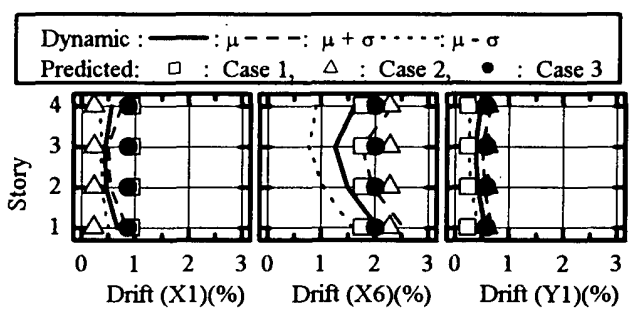

(a2) Model-A2

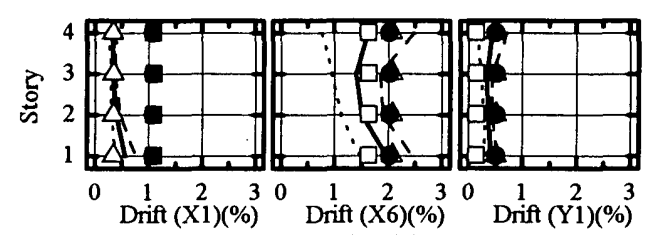

(b) Model-B

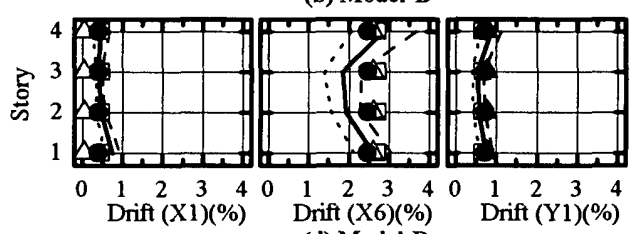

(d) Model-D

図 7 構面の最大層間变形角の推定結果

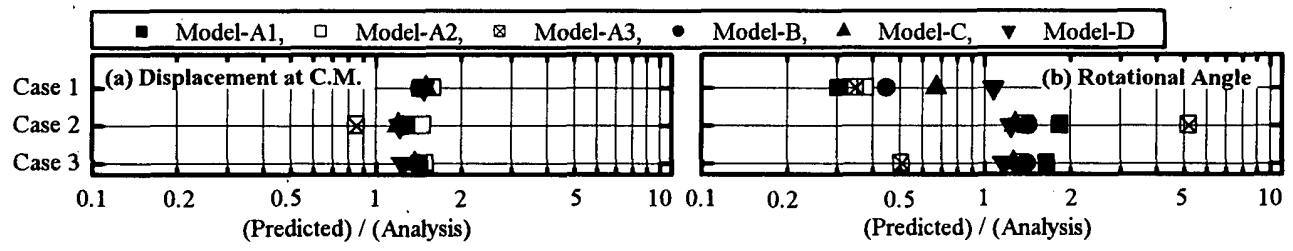

図 8 最上階重心变位・回転角の推定精度

は Model-A3，Model-B ともに時刻 歴応答解析の結果を過小評価して いる. 一方の Case 2 ではモード形 の変動の著しいModel-A3 で大棺 に過大評価する一方, Model-Bで は良好に対応していることがわか る.最後にCase 3 では, Model-A3 ではやや過小評価となっているも のの Model-B では Case 2 と同様に 良好な対応を示しており, 3 者のう ちで安定して最も対応が良好とな っていることがわかる。

ここで, Model-A3 において Case 2 では他と比較して応答が小さめ に推定された要因を検討する。図 10(a)に, Model-A3 での等価 1 自由 度系モデルにおける等価質量比

$\left(\Gamma m^{*} / \Sigma m, m_{1}{ }^{*}\right)$ と等価変位 $D_{1}{ }^{*}$ の関 係を示す。図 10(a)より, モード形 の変動を無視した Case 1，2 では $\Gamma m^{*} / \Sigma m$ の值は一定となる一方，乇 ード形の変動を考慮した Case 3 で は変位の増大とともに $m_{1}$ ”が急激 に增大して Case 1 に漸近している ことがわかる.その結果，図 10(b) 


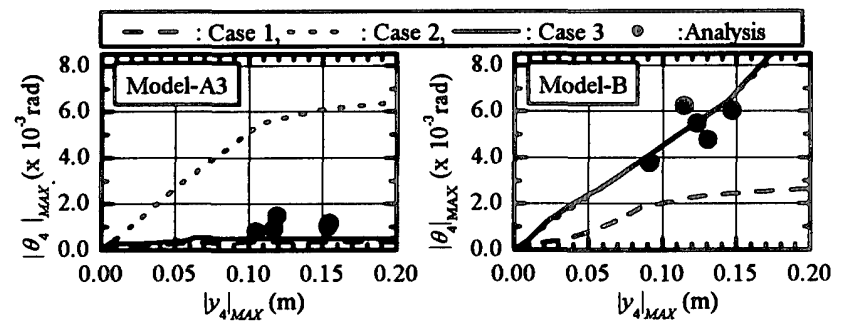

图 9 最上階重心变位と回転角の関係

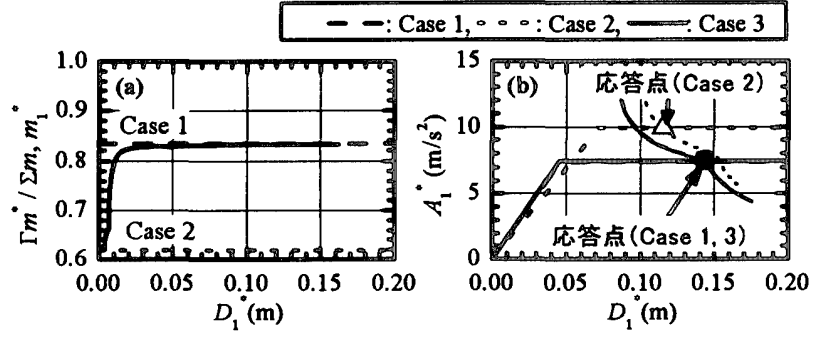

图 10 等価 1 自由度系モデルによる在答推定例(Model-A3)

に示すように等価 1 自由度系モデルの $A_{1}$ *-D $D_{1}$ *関係は Case 1 と Case 3 でほぼ同一となり，両者の推定結果は等しくなる，一方で, Case 2 では塑性化の進展に伴う等価質量の増大が無視される結果 $A_{1}{ }^{\circ}$ が過大 評価され, 応答変位が過小評価される。

以上により，モード形の変動を無視した Case 1, Case 2 と比較して， モード形の変動を考慮した Case 3 が最も精度が高いことがわかる.

\section{6 まとめ}

本論文では，文献 12)で示した等価 1 自由度系による非線形地震态 答推定手法の理論的背景を概説し，特に 1 軸偏心建物を縮約した等価 1 自由度系モデルと多層平面骨組を縮約した等価 1 自由度系モデルの 関倸に着目して議論を行った．次いで，提案する手法と既往の手法と の応答推定精度の比較を行った．結論を以下に記す。

(1)偏心建物を縮約した等価 1 自由度系モデルにおいて, 回転中心から 重心までの距離と, 重心位置から等価質量の位置までの距離は逆比 例の関係にあることを示した．また，偏心建物における回転中心か ら等価質量までの距離は, 多層平面骨組における等価高さと力学的 に等価であることを示した．

(2)偏心建物の応答を精度良く推定するためには，モード形の変動を考 慮する必要がある．N2 method では，モード形の変動を無視し仮定 する変位分布で回転成分を無視するため，回転成分の応答を過小評 価する傾向にある．また，仮定する変位分布として弾性 1 次モード 形を用いて回転成分を考慮する場合でも，モード形の変動の影響が 著しい場合には応答変位を精度良く推定できない.

(3)女献 12)にて筆者らが提案する応答推定手法ではモード形の変動の 影響を考慮しているため, 全モデルで安定して最も良好な推定結果 となった.すなわち本論文において検討したモデルにおいては,弾性 時での 1 次等価質量比の範囲は 0.619〜0.800であったが，全モデル で最上階での構面の変位を概ね良好に推定することができた． 本論文での検討結果より，文献 12)で示した推定手法は 1 次等価質 量比が 0.6 以上でせん断变形が卓越する立面的に整形な建物であれば 概ね適用可能であるが，非線形応答が大きくなるにつれて層間変形角 の推定精度のばらつきが大きくなる傾向がある．また，立面的に整形 な建物であっても中層以上で連層耐震壁を含む建物の場合には，曲げ
变形の影響により各層で弾力半径比や偏心比が大きく異なるため 2.1 節の条件 4)を厳密には満足しない場合も多い，しかし，連層耐震壁を 含む 4 層程度の低層建物の場合にはその固有モードが式(5)〜(8)によ り近似できる事が田村・荒川らにより示されている ${ }^{20)}$. 従ってこの場 合には文献 12)で提案した応答推定手法は適用可能であると思われる. 一方で,ピロティ偏心建物のように特定層のみに偏心のあるような場 合やセットバックを有する建物の場合には，等価単層 1 軸偏心系モデ ルへの縮約が困難となるため文献 12)で提案した応答推定手法は適用 困難である.この場合には多層 1 軸偏心系モデルから直接等価 1 自由 度系モデルに縮約する必要があるが，今後の検討を要する. また，多 方向地震入力の影響および 2 軸偏心建物等のより一般的な場合への拡 張に関しては, 稿を改めて発表する予定である.

謝辞 : 本研究の実施に当たっては, 日本学術振興会・科学研究費補助 金（基盤研究(B) (2)「平面計画上の椿造非整形性を有する R C 造建築 物のねじれ応答制御に関する研究」, 課題番号: 12450221, 研究代表 者：中禁 良昭) の援助を受けた。ここに謝意を表す。

\section{考女献}

1) Applied Technology Council : Seismic evaluation and retrofit of concrete buildings(ATC-40), Report No. SCC96-01, 1996.11.

2) Federal Emergency Management Agency : NEHRP Guidelines for the Seismic Rehabilitation of Buildings, FEMA-273, 1997. 10.

3）建設省住宅局建築指導課：改正建築基準法法令集，2000.7

4) P. Fajfar, M. Fishinger : N2-A Method for Non-linear Seismic Analysis of Regular Buildings, Proceedings of 9th World Conference on Earthquake Engineering, Vol. V, pp. V-111-116, 1988. 8

5）會本 洋, 栜使川原 正臣，小鹿 紀秀，五十田 博：多層建筑物の等

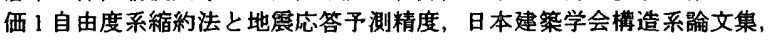
第 546 号, pp.79.85, 2001. 8

6) A. S. Moghadam, W. K. Tso : Damage Assessment of Eccentric Multistory Buildings Using 3-D Pushover Analysis, Proceedings of 11 th World Conference on Earthquake Engineering, CD-ROM, 1996. 6.

7) P. Fajfar, V. Kilar, D. Marusic, I. Perus, G. Magliulo : The Extension of the N2 Method to Asymmetric Buildings, Proceedings of the Fourth Forum on Implications of Recent Earthquakes on Seismic Risk, pp.291-308, 2002. 5

8) 藤井 堅志, 中埜 良昭, 真田 靖士：单層 1 軸偏心建物の非線形応答

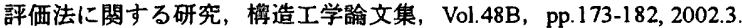

9) 藤井 賢志, 中埜 良昭, 真田 靖士：多層 1 軸偏心建物の非線形地罢 応答評価法に関する研究，コンクリート工学年次踚文集, Vol. 24, No. 2, pp.173-182, 2002. 6 .

10) 藤井 賢志, 中樊 良昭, 真田 靖士: 多層 1 軸偏心建物の等価 1 自由 度系への縮約, 第 11 回日本地震工学シンボジウム C D-R OM羭文集, Paper Ref. 378, 2002.11.

11）藤井 賢志，中埜 良昭，真田 靖士：単層 1 軸偏心建物の非線形応答 評価における直交方向構面の㓮性低下の影響, 構造工学踰文集, Vol.49B, pp. 221-234, 2003.3.

12）藤井 堅志, 中埜 良昭, 真田 靖士：一方向入力を受ける多層 1 軸偏 心建物の非線形地震応答評価手法, コンクリート工学年次論文集, Vol. 25 , No. 2, pp.7-12, 2003. 7 .

13）藤井 蜸志: 多層 1 軸偏心建物の非線形地震応答評価手法に関する研究. 東京大学博士論文, 2002.12

14）志賀 敏男：構造物の振動，共立出版，1976.6

15）枈田 明徳：最新 耐震構造解析，森北出版，1981.6.

16) 国土交通省住宅局建築指迸課 : 2001 年度限界耐力計算法の計算例とその 解説, 2001. 3.

17) Shibata A. Sozen M. A : Substitute-structure method for seismic design in R/C, Joumal of the Structural Division, Proceedings of the ASCE, Vol. 102 No. ST1, pp.1-18, 1976.1

18) Takeda, T., Sozen, M. A. and Nielsen, N. N. : Reinforced Concrete Response to Simulated Earthquakes, Journal of the Structural Division, Proceedings of the ASCE, Vol. 96, No. ST12, pp. 2557-2573, 1970.12.

19）日本建築センター：建筑物の構造規定，1997.5.

20）田村 充, 荒川 利治 : ねじれ振動を有する梅造物の直皘計算による固 有值解析 (連層䩂震壁が偏在する耐震壁ーフレーム連成構造), 日本建筑

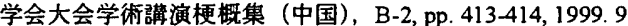

（2004年 3 月 15 日原稿受理， 2004 年 5 月 18 日採用決定） 